\title{
The need for an integrative theoretical model to determine the personality of terrorists
}

\author{
Ziyad Abdulqadir ${ }^{1} \mathrm{~A}$ \\ A University of Warsaw, Poland
}

Received: June 27, 2021 | Revised: August 19, 2021 | Accepted: August 31, 2021

DOI: $10.33445 /$ sds.2021.11.4.1

\begin{abstract}
Terrorism is a threat to the whole of humanity, counterterrorism is a collective responsibility which requires extreme levels of cooperation and coordination between nations to reduce terrorism and terrorist behavior, in this regard, several international laws, decisions and agreements have been formulated or signed to tackle the problem. In recent years terrorism has become a real challenge for many countries of the world and for all humanity, because terrorism and aggressive behavior of terrorists, annihilated a lot of people, destroyed the infrastructure and economic structure of the group of nations of the world. The thought and extremist ideology of some groups making human in the circle of fear, constant anxiety, and affected the progress of nations in all sides of human life, also affected the human development, and the open humanitarian ideas.

Counter-terrorism has become an international issue, and study about it is important that should take into consideration the theoretical and practical aspects. However, with the lack of internationally accepted definition and theories about terrorism as a phenomenon, perhaps it is not surprising that there is a similar shortage of theories on how to combat it. Moreover, the increasing complexity and the wider threat of the phenomenon of terrorism and extremism, with the influx of actors and a range of motivations, strategies, tactics, and evaluation tools are available on how to confront such threats are necessary in guiding the process of policymaking to combat terrorism.

This article aimed to claim the necessity of forming a theoretical model to determine the personality traits of the terrorist and distinguish them from the pathological personality. (Mental illness). According to some hypotheses and theories of the personality of terrorists and a comparison between the two personalities: "terrorist and abnormal personality" with a number of studies that dealt with them, thus, there is a need for a theoretical model to determine the traits of the personality of terrorists.
\end{abstract}

Key words psychology of terrorism, personality of terrorist, extremism, terrorist traits, counterterrorism.

\section{Introduction}

The psychological movement began to focus on and interpret terrorist behavior from the late 1960 s to the mid-1980s. The scientific beginning was to research terrorist behavior as a scientific activity (Layla, 2017). The dominance of psychoanalytical approaches to terrorism has led to serious misleading of terrorists' psyche because they were focusing that a terrorist is a psychopathic person, terrorism is abnormal behavior, and however, this perception quickly fell apart because it faced explanatory shortcomings at both the theoretical and evidence levels of reality. This may seem outrageous to many, but there is almost unanimity among researchers on the subject of terrorism, that terrorists are normal individuals and not psychologically psychopaths, according to Silk, 2014 that all psychologists can say with

\footnotetext{
${ }^{1}$ Corresponding author: Doctoral Candidate Faculty of Psychology, e-mail: abdulqadir.ziyad@psych.uw.edu.pl, ORCID: 0000-0002-0558-7002
} 
confidence after period years of researches on terrorism, that the most prominent characteristics of terrorists are that they are normal. If terrorists are normal or rational people who are fully aware of what they are doing, what prompted the person to join terrorist groups? Or doing a terrorist act? There are several theoretical approaches to the study of terrorists, which can be combined and create a complementary model to explain the personality traits of terrorists.

\section{Results and discussion}

\section{Terrorist personality}

There is still a dispute among scholars about the existence of a terrorist personality, most of them do not believe in the existence of a type of this personality. According to Borum 2004, there is no terrorist personality, nor is there any accurate profile psychologically or otherwise of the terrorist.

Terrorist Personality is a persona which is characterized by the behavior of aggressive authoritarian and bloody, it is a pattern of behavior which is characterized by fraud and deceit and recklessness and impulsivity, without regard for the result of his safety and the safety of others, as well as the excess of cruelty to others, destruction of their property, and the lack of appreciation of responsibility with extreme recklessness and not giving any attention (Al-Naimi 2013).

A terrorist is a person who resorts to illegal violence or threat to achieve political goals, whether from the government or individuals and groups revolutionary opposition (Atallah, 2004). The importance of the definition of terrorism phenomenon reached to a great significance of encourage States to hold conferences, seminars and to identify their concepts, components, and causes, generally in this way appeared two trends; the first is Physical direction and the second is Moral direction or "Emotional" therefore, the first trend is based on the material foundation, therefore the first trend is based on the material foundation for the definition of terrorism on the component behavior of the crime or their constituent acts, according to that, terrorism is defined as an act or a series of specific actions which aim to achieve a particular goal (Jalal Izz al-Din, 1986). This concept has led to the definition of terrorism on the basis of census crimes that is a terrorist without looking for the purpose or goal of the terror action, in this direction Bruce Palmer has indicated that the terrorism is definable, whether the acts comprising the means are being their enumerated and defined in a precise and objective manner without discrimination with respect of the actor such as individuals, members of the political groups and agents of state (Shebbi, 2005), and then proponents of this method went to the sufficiency census works or acts that are terrorist murder, assassination, kidnapping, hostage-taking and piracy, and it is no secret what surrounds this identification of deficiency from where exceeded on the most important element of the terrorist crime, is a purpose or a political goal as exclusive selection of specific crimes as a terrorist, it leads to the exit of many of the crimes in the circle of terrorism, whether does not mention within this type of crime is bypassing what may have adopted science and technology of a new form of terrorist crimes evolution, however, some of aspect of jurists have trended to identify specific features of terrorist crimes to distinguish them from other and not sustainment with the census exclusive (Al-Khalaf \& Al-Shawi, 1982).

\section{Personality Traits of Terrorist}

Although there is an almost consensus or near-consensus among scientists, scholars, and thinkers that terrorism is an act of violence that violates humanitarian laws, they did not reach a comprehensive procedural definition for many reasons, primarily ideological and political differences which makes views differ according to interests and objectives, as well as the political nature of terrorism and the diversity of 
its forms and methods (Haidari, 2010). The terrorist personality is the result of a set of interlocking factors that include the metaphysical, psychological, social and economic aspects, mental abilities and experiences, mood and emotional state, as well as other environmental and cultural factors (AlNaimi). The terrorist personality is the result of a set of interlocking factors that include the metaphysical, psychological, social and economic aspects, mental abilities and experiences, mood and emotional state, as well as other environmental and cultural factors (AlNaimi). There are some common traits of the terrorist elements, which motivate and push them to join extremist groups, commit crimes, and practice violence, which was confirmed by a number of mental health experts and scholars, who confirmed that the personality of terrorist is characterized by a number of common features such as duality and behavioral disorder. As Ahmed Okasha 2020 a professor of psychiatry indicated that the extremist groups are all characterized by being far from logical, and adopting superstitious thinking related to misconceptions about the hereafter, reward and punishment, adding that the personality of the terrorist element is never able to taste beauty and love because it has a rigid and psychologically poor personality.

One of the motives for engaging in terrorism is not supposed to be "the cause of the ideology of the group. However, as Martha Crenshaw 2008 , noted the popular image of a terrorist as an individual motivated exclusively by a deliberate and profound political commitment that obscures the more complex reality. That reality is motivated by the systematic link of a terrorist and the involvement of terrorism is very different across different types of groups within the groups they individuals organizing those groups may change over time. Crenshaw suggested that there are at least four categories of motivation among terrorists: The opportunity to act, the need for belonging, the desire for social status, and get the material reward. Post1990 , went further to suggest that terrorism is an end in itself, s stated as independent of any political or ideological goals. The central argument for this situation is that individuals become terrorists in order to join terrorist groups and commit acts of terrorism, and based on a review of the existing literature, there are three motivational themes: injustice, identity, and Belonging (Borum, 2004).

\section{Extremism and its relationship with}

\section{terrorism}

Extremism is a term used to denote everything that contradicts the Equinox, it confronts the values, norms, and customs common in the society and embraces the values and standards of their offense. Due to the relative extent of moderation and variability from one society to another, according to the values and the culture and customs of each, are several concepts of extremism which make it difficult to determine their frames (Al-Jundi, 1989). However, some researchers have tried to reach a definition of the concept of extremism. We address the most important ones: Ideological extremism is one of the forms of extremist which exits from the rules of the intellectual or cultural community (Al-Fakhrani, 1998). Extremism is associated with the inertia of mental dogmatism and intellectual isolation and, in fact, this is the essence of the general trend which revolves around each labeled extremist group, as extremism in this sense is a closed way of thinking, which is characterized by the inability to accept any beliefs or opinions that differ from the beliefs of another person or group (Naim, 1990). In those cases where there is a resort to violence (individually or collectively) by the extremist organization in order to impose its values and standards, or with the aim of bringing about a change in the values and standards of the society to which they belong and to impose by force their opinion, this is a form of terrorism, and even organized terrorism (Khashish, 2014).

Extremism in language means to stand in the side away from the middle and its origin in the sensory like extremes in the stand or sit or walk then moves to sentiments and moral such as extreme in religion or thought or behavior. Thus, we can say that extremism in the language means to stand in the party, side or end of the thing and the party in terms of energy aspects of 
the thing and the side everything run its course (AL-Wajeez dictionary, 1999). And extremism is a normative word that means contrary to public line or normal which is determined by traditions and customs, legal standards, and religious prevailing in the society which makes the concept replaces difference between communities, therefore flexible environment may see wrongfulness in certain actions while hardliner sees the opposite. In Webster's Dictionary that extremism refers to strongly away from what is logical, or reasonable, or acceptable, such as extremism in the opinion and so on. The word of Extreme refers to any respect to be contradictory and, in the distance, apart from each other such as the pain emotion, or pleasure. (Webster, 1984). Extremism is termed as excessive, extreme, militancy and committed, whether in thought or behavior or both and then Extremism is overstepping the extent of moderation with overproduction, in the sense exceeded intellectual frameworks or behavioral standards accepted in society (ALJundi, 1989).

The extremism is an individual taking a tough stance is characterized by estrangement in its responses to social situations that charge in the environment in which live there, and maybe extremism positive in full acceptance or negative in the direction of outright rejection, and is fairly moderate in the middle of the distance between them (Bloder, 2006). Extremism is a style of closed thinking that characterized by the inability to accept any beliefs that differ from the beliefs of the person or group or tolerating with them, this type is characterized by perception of belief is based on the belief that honest and truthful at all eternally fit every place and time, there is no area for discussion and to search for evidence to confirm or deny to condemn all different from the belief, and impose a belief on others by force, and refer to the belief in the interpretation of any issue in the universe, and facing of difference of opinion or interpretation of violence (Ismail,1996).

Extremism is a process of supporting or engaging in activities that are considered a violation of important social standards. The idea of extremism as it is referred to the violent extremism theory that idea of extremism is heading a movement in the direction of support or extremist behavior. Therefore, the ideology of extremism with some people has common aims or objectives either in supporting or engaging in extreme behavior. Extremism is a matter of degree to support the positions of actual violence or engage in these situations. As well, in order to seek to restore the personal significance that the extremists had lost after determining the target and ideological elements and determine the means of violence in line with this aim, those extremist people communicate with others as a dynamic group because all of them hold the same ideology and acts of aggression and violence that they do, they justify the thought of extremism which they have as it is a way to achieve personal importance or in other words way to achieve Significance of Personality (Kruglanski \& others, 2014). And these extremists initially didn't face social, political and economic difficulties or confront with others with sound ways of thinking or they did not think rationally in order to overcome the difficult situations that they were undergoing. On the contrary, they were thinking without rationally in all positions and don't believe in mental logic proper to confront their difficulties or compensation for what they have already lost, but are facing the difficulties without logic, which does not accept the laws and social customs, they acting in their acts of aggression, violence and terrorism (Kruglanski \& others, 2009).

\section{Psychological Theories:}

Psychological theories of extremism and terrorism are primarily concerned with understanding the group factors, which contribute to extremism, violent political activity, and acts of terror. The main area of focus in the discipline and research on the psychological theories of terrorists is the mental functioning and personality of the individuals. The authors in this field are not necessarily psychologists or psychiatrists by profession but, rather, draw their conclusions on psychological responses to sociological influences or the results of individual mental illness and/or 
trauma (Nasser-Eddine and others, 2011).

There are many opinions, trends, and theories that explain the psychological factors of the terrorist personality. The most important theories are briefly as follows: -

\section{- Psychological analysis theory:}

This theory is based on the fact that terrorist behavior is a product of the conflict between the "Id" and the "Ego", if Ego succeeds in its endeavors, the behavior is balanced and the individual lives with the environment, but if it failed, the behavior may become deviant or criminal in its directions. Freud argues that there is a destructive aspect in all men; therefore, the individual is anti-social, cultural, and humanitarian trends. There is no doubt that early writings on the psychological dimensions of terrorist behavior were dominated by psychoanalytical structures, and there were two themes that continued of these structures, First; The motives of terrorism are more unconscious and arise from hostility towards one of the parents, and Second Terrorism is the result of early abuse and mistreatment. (Borum, 2004, p.18). This is the outcome of subconscious conflicts experienced during the period of his early childhood and the individual remains in the subconscious.

Freud believes that the psychological system consists hypothetically (Id, ego, superego). Id: is the source of the vital energy, the psychological that the individual is born with, it contains what is fixed in the composition of the body, and includes instincts, and sexual innate motives, and aggression, therefore, is far from norms, social values, and its activity is dominated by the principle of pleasure and pain, that is, to rush to satisfy its motives urgently in any form. Ego: It is the center of feeling, the perception of the external sense, the perception of the inner sense, or the processes of rationality, Freud believe that it is an executor of personality, works in the principle of reality, which is based on order to preserve, and achieve the value of social harmony. Supergo: the repository of ideals, ethics, conscience, social norms, traditions, values, righteousness, goodness, and justice, it is the internal authority (Al-Jizani, 2012: 99-100).

\section{- The rational choice theory:}

The theory that terrorist action derives from a conscious, rational, calculated decision to take this particular type of action as the optimum strategy to accomplish a sociopolitical goal (Sandler, Tschirhart, and Cauley 1983, Lapan and Sandler 1988, Crenshaw 1992, Wilson 2000). According to the Rational Choice Theory, an individual decides whether or not to participate in an act of violent extremism, political violence, or terrorism on the basis of a cost-benefit analysis. The benefits of participation are weighed against the costs associated with participation. If the benefits are greater than the costs, then the individual decides to participate (Nasser-Eddine and others, 2011). Rational choice theory, derived from economics, assumes this behavioral proclivity as a given and attempts to explain how changes in policy the rules of the "game" that is played between terrorists and governments might predictably alter behavior. According to Victoroff 2005 which suggested that rational choice analysis is a powerful tool for discovering theoretically valid and surprisingly counterintuitive forces that probably influence terrorist and government behaviors. Since rational choice theory considers both policy and individual behavioral responses to policy, it combines the top-down and bottom-up approaches Game theory, based on this "assumption of rationality" in strategic choice formulations (Jeff Victoroff, 2005). This theory is often applied to predict the utility of various policies. That is, this theory can be applied to ascertain whether, for example, defensive policies such as metal detectors and other processes that increase the costs of terrorist attacks and curb the likelihood of success or proactive measures such as attempts to stymie resources or sponsors are likely to be effective (Sandler \& Siqueira, 2009).

\section{- Social Learning Theory}

Social learning theory is a general theory of crime and criminality and has been used in research to explain a diverse array of criminal behaviors. The theory as proposed by Akers is centered around the idea that "the same learning process in a context of social structure, interaction, and situation produces both 
conforming and deviant behavior. The difference lies in the direction of the balance of influences on the behavior (Akers and Sellers, 2004: 85). Social learning theory is a social behavioral approach that emphasizes the "reciprocal interaction between cognitive, behavioral and environmental determinants" of human behavior (Bandura, 1977: vii). Bandura's $(1973,1998)$ social learning theory of aggression suggests that violence follows observation and imitation of an aggressive model, and a variant of this theory has been invoked to explain terrorist behaviors not as the consequence of innate aggressively but of cognitive reconstrual of moral imperatives (Jeff Victoroff, 2005). According to Orabi, 2007 the social learning theory emphasizes that learning and the reinforcement of aggression with influences are what leads to terrorism. The social learning theory is persuasive that people learn to be aggressive by observing others behaving aggressively to achieve a goal to be rewarded as a direct result of the commission of acts of violence (Richard J. \& David L. Hughbank, 2007).

\section{- Relative Deprivation Theories}

Relative deprivation theory is based on an individual believing that he/she is deprived of something when he compares him/herself to others economically, politically, or socially. This model is mainly used by sociologists, some economists, and psychologists. This means that individuals who score poorly on socioeconomic variables are at risk of extremism and violence. It stems from the belief that poor socioeconomic performance leads to frustration, which makes them susceptible to extremism (Nasser-Eddine, Minerva, Bridget Garnham, Katerina Agostino, and Gilbert Caluya, 2011). Deprivation theory has been proposed that economic disparities cause terrorism (Gurr, 1968; Gurr, 1970). Gurr defines relative deprivation as a person's belief to receive less than deserved, and the term furthermore entails the perception that one's group is being treated less well than other groups (Feddes, Mann, \& Doosje, 2015). He theorizes that this collective discrepancy creates frustration and, in turn, contributes to the use of violence. Galtung 1969 argued that the situation most likely to provoke aggressive behavior is one in which individuals find themselves in a state of disequilibrium along various sociopolitical dimensions of status (LIA Brynjar, Skjølberg Katja, 2000, p11). Several systematic studies of relative deprivation theories have supported the hypothesised relations between frustration and aggression both at the microand macro-level of society Gurr terms this gap between expectations and satisfaction relative deprivation (Gurr, 1970).

\section{- Behavioral Theory:}

This theory considers that terrorist behavior is a learned behavior that the individual learns from the surroundings in which he lives, Skinner 1965 confirmed that imitation has a prominent role in learning aggressive behavior, and that is through what the individual observes in the family environment or what he sees in the various media or through imitation (Al-Naimi , 2013). Pavlov argues that human behavior is only a set of habits that an individual has learned or acquired during different stages of development, and that behavioral disorder is the result of one of the following factors:

1) Failure to acquire or learn appropriate behavior.

2) Learn inappropriate behavioral stylize.

3) Confronting an individual with contradictory consent that cannot make the appropriate decision.

4) Link individual responses to new stimuli to trigger a response. (Abu Eita, 1997; 152, Abu Howaishel, 2013). This theory is due to the mismatch in the behavior of the individual with the group due to impairment in the growth of personality components cannot recognize the behavioral standards, and this reference is due to the exposure of a person to environmental influences of some kind or the result of experiences, and influences experienced in his life, which led to the acquisition of a set of habits, and trends either towards oneself or towards others who do not achieve compatibility with himself or with the society in which they live, which deviates from the norms of behavior prevailing in society (Sharkawy, 1986, Abu Howaishel, 2013).

- Theory of Cognitive Behavioral
Modification


Cognitive-behavioral modification is an approach to cognitive behavioral therapy that focuses on changing negative self-talk and life narrative to positive self-talk the premise of this approach to treatment is that negative self-talk can be reflected in a person's behaviors. In other words, bad thoughts lead to bad actions that usually lead to bad results. The goal of cognitivebehavioral modification is to change a selfdescribed narrative or life story from negative to positive. This is done by focusing on the client's strengths and flexibility. The cognitivebehavioral modification also helps clients forgive themselves for their bad actions in the past and move forward with hope and positivity for the future with a positive change in perspective and life narrative, the client's actions will predictably follow suit (Gonzalez, 2021). The theory of Cognitive Behavioral Modification is considering that the interaction between the internal conversation in the individual, and cognitive structures is the direct cause of the process of changing the behavior of the individual, the internal talk creates motivation in the individual, and helps him to classify his skills, and direct his thinking to do the required skills, and that there is a goal behind the change of the individual modern internal. It is therefore necessary to determine the individual's need for something he wants to achieve, what he wants to bring about in the environment, how to understand triggers, and for anything that attributes the reasons for his behavior and expectations (Mahdi, 2007).

\section{- Theory of self-regulation:}

Self-regulation theory is a system of conscious personal management that involves the process of directing an individual's thoughts, behaviors, and feelings to reach goals. Selfregulation consists of several stages and individuals must act as contributors to their motivation, behavior, and development within a network of mutually interacting influences. Baumeister 2007 claims self-regulation contains four components: standards of desired behavior, and motivation to fulfill standards, Observe the attitudes and thoughts that precede the breaking of the aforementioned norms, and willpower. Pandora believes that self-regulation means an individual's ability to control his or her own behavior. The emotion that gives it a sense of pride, and selfsatisfaction is more desirable when it is done than the emotions that lead to self-criticism, that people are constantly making standards for themselves and then compare between them, and their performance to reach those standards (Bandura, 1991).

\section{- Psychopathic personality}

Psychopathic personality refers to the deviation of the individual from normal behavior, deviation in anti-social behavior, and outward values, standards, ideals, and rules. Psychopathology is a psychosocial and economic problem facing society, and concerns psychologists, social, education, legal and security men because of its negative effects on the individual and society and the threat it poses to mental health, Al-Daheri 1999, Defined that psychopathic personality includes personal qualities that are not socially compatible, professionally, they are seriously disturbed by social and moral constraints, are emotional, and have no ability to fulfill the demands of life (AlDaheri, 1999). Henderson 1947 considers psychopaths as unusual people from early childhood, their emotional response or their general behaviors, but they have not reached a degree of intensity that would make them sick or mentally retarded. Many lines of thought do not support the popular claim that antisocial behavior is typical or common among terrorists. Much evidence supports the idea that terrorists are far from being pariahs and afflicted with mental illness. If a terrorist is revealed to have mental disorders, it cannot necessarily be concluded that the disorder was the cause and not the result of terrorist activity. There is no significant evidence in the available literature of a link between psychopathology and terrorism. As with general criminal activity, there are undoubtedly cases in which individuals engage in terrorism due to a pre-existing mental disorder (Piccinni and others, 2017). 


\section{Conclusions}

The characteristic of terrorism and its trends in the current era of globalization is that it is linked to power and authority more than any theoretical and empirical orientation. Perhaps this is the main reason why differences remain about the interpretation of terrorism. It is certainly the main reason for the continued survival of terrorist organizations. There is no theory or approach that can explain the personality of the terrorist, and it may appear because there is no unified agreement on the definition of terrorism and the interpretation of this phenomenon in general.

The theories that explain the personality of the terrorist see the terrorist crime in a limited and partial way and do not promote the level of the overall view of the deviant problem, as they contain all the vocabulary and formations of an individual or collective crime in society. Some theories have interpreted or focused on the genetic aspect as an influential factor in the emergence of criminal tendency in which there is a lot of exaggeration. There are other factors that contribute to terrorism, including organic, social, psychological, economic, cultural, and religious factors, some of which begin to influence the individual's childhood. The social, economic situation, unemployment, the volatile political situation, and self-interests, which encourage terrorist operations, and therefore the family and school must be the basis of social education because they are the main pillar in building the personality of the individual. Each of the theories and comparisons has its importance in explaining the personality of terrorists, but the relative balance of importance varies from one reason to another, and this importance changes with time and changing circumstances. There are many points of view to understand the personality and traits of terrorists, and there are also a set of factors that push individuals to join extremist groups. Researchers and specialists have presented great opinions to explain terrorism and terrorist personality traits, but according to their theoretical premises or intellectual experiences, and because of the extreme complexity of the phenomenon of terrorism. Researchers agree on many aspects that surround it, including identifying the characteristics of the personality of terrorists and the definition of the terrorist. Therefore, in order to understand a lot about the aspects of the personality of terrorists and to be beneficial to the counter-terrorism policy, it is possible and necessary to form an integrative theoretical model to explain the personality of the terrorist and compare it with the normal personality.

\section{References}

Akers, R. L., Sellers C. S. (2004). Criminological Theories: Introduction, Evaluation, and Application (4th ed). Los Angeles: Roxbury Publishing.

Abu Howaishel, Raed Ahmed, (2013) Psychopathological personality and its relationship to psychological unity and selfesteem among prisoners held in Gaza Central Prison, Department of Psychology, Faculty of Education, Islamic University of Gaza.

Abdul Khaliq, Ahmed, 1998, the basic dimensions of personality, Dar Al-Marifah University for Printing and Publishing, Alexandria, p. 41.

Armando Piccinni, Donatella Marazziti and Antonello Veltri,
(2017) Psychopathology of terrorists, Cambridge University Press: 21 September, DOI: 10.1017/S1092852917000645.k

Al-Ansari, Badr 1996, The Big Five Factors in Personality, Theoretical Presentation, Journal of Psychology, No. 41, Year 10, pp. 619.

Al-Haidari, Ibrahim, (2015), Sociology of Violence and Terrorism, Dar Al-Saqi, Beirut Al-Naimi, Layla Ahmad Ezzat, (2013), Terrorist Personality and Factors Affecting its Formation, Psychology Academy, WWW.acofps.com

Al-Dahri, Salih Hassan (2008): Fundamentals of Psychological Compatibility, Behavioral Disorders, and Emotional Theoretical 
Foundations, I 1, Safaa House for Publishing and Distribution, Cairo.

Al- Fakhrani, Khalid Ibrahim, 1998, The Effectiveness of Rational Emotive therapy in the Face of some Mental disorders among Extremists, Psychological Counseling Magazine, Cairo, Psychological Counseling Center, Ain AL-Shams University, p. 257.

Al-Jizani, Mohammad Kazem (2012): The concept of self-maturity social between reality, and idealism, I 1, Dar Al-Safa for publication and distribution, Amman, Jordan.

Al-Jundi, Amina, (1989), The Extremism among Young People in the Egyptian Universities, AlManar magazine, No. (151), Cairo, p. 64.

Al-Naimi, Laila Ahmed Ezzat, (2013), The terrorist personality and the factors affecting its formation, Academy of Psychology, Section: Criminal and Cyber Psychology, University of Baghdad / College of Education for Girls.

AL-Wajeez dictionary, (1999), The Arabic Language Academy, AThe Intermediate Dictionary, Cairo, Ministry of Education, p. 389.

Atallah, Imam Hassanein (2004) Terrorism, the legal structure of the crime - University Press, p. 97.

Bandura, A. (1977). Social Learning Theory. Englewood Cliffs, NJ: Prentice Hall.

Bandura, A. 1973. Aggression: A social learning analysis. New York: Prentice Hall. 1998.

Banadora.A (1991) Self -Efficacy Conception of Anxiety Journal of Personality and Psychology, Anxiety and Self- Focused Attention. Vol .60. (5).

Baumeister, Roy F., Schmeichel, Brandon J., and Vohs, Kathleen D. (2007) Self-regulation and the executive function: the self as controlling agent, Social psychology: handbook of basic principles, New York, NY, United States, Second edition, Guilford Press, ISBN 9781572309180.

Bloder, Chirema, (2006). The Causes of Extremity in Changing World, Toronto University.

Bruce Hoffman (2002) Rethinking Terrorism and Counterterrorism Since 9/11, Studies in

\section{Conflict \& Terrorism.}

Borum, Randy. (2004). psychology Terrorism. Tampa: University of South Florida.printed in the United States of America.

Brian Jenkins (1986) - Referred to by Ahmed Jalal Izz al-Din - Terrorism and Political Violence Freedom Book, p. 26.

Crenshaw, M. (1992). Decisions to use terrorism: Psychological constraints on instrumental reasoning. International Social Movements Research. 4:29-42.

Da Raad, B. (2000). The Big Five Personality Factor: The Psycholexical Approach to Personality. Toronto: Hogrefe \& Huber Publishers.

Digman, J. M. (1990). Personality Structure: Emergence of the 5 Factor Model. Journal: Annual Review of Psychology, 41 (1), 436.

Ewen, R. B. (1998). An Introduction to Theories of Personality. Mahwah, NJ: Lawrence Erlbaum Associates.

Feddes, A. R., Mann, L., \& Doosje, B. (2015). Increasing self-esteem and empathy to prevent violent radicalization: A longitudinal quantitative evaluation of a resilience training focused on adolescents with a dual identity. Journal of Applied Social Psychology, 45(7), 400-411.

Imam Ahmad, (August 14, 2020). Psychology professors identify the most prominent features of the "The personality terrorist": ambivalence, defeatist, behavioral disturbance, AL-Watan, Electronic portal, 82 bis Abdel Aziz Fahmy Street - Heliopolis.

Gurr, T. (1968). Psychological factors in civil violence. World Politics, 20(02), 245-278.

Gurr, Ted Robert (1970) Why Men Rebel (Princeton, NJ: Princeton University Press).

Gosling, S., Rentfrow, P., \& Jr, W. (2003). A Very Brief Measure of the Big, Five Personality Domains. Journal of Research in Personality, 37, 504-528.

Gonzalez, Karin (07/05/2021). CognitiveBehavior Modification Approach by Meichenbaum, Lesson Transcript, study.com. Henderson, D. K., (1947) "Psychopathic States". W. W. Norton Co. New York. Vol. II, No.2, page 84 . 
Hudson, Rex A. (1999) The Sociology and Psychology of Terrorism - Library of Congress, A Report Prepared under an Interagency Agreement by the Federal Research Division, Library of Congress, Editor: Marilyn Majeska, Project Managers: Andrea M. Savada, Helen C. Metz, Federal Research Division, Library of Congress, Washington, D.C. 20540-4840.

Ismail, Izzat Sayed, (1996), The Psychology of Extremism and Terrorism, Kuwait, Yearbook of the College of Arts, No. (16), Thesis (11), p. 218

Jeff Victoroff, 2005, The Mind of the Terrorist: A Review and Critique of Psychological Approaches, The Journal of Conflict Resolution, Vol. 49, No. 1 (Feb., 2005), pp. 342, Published by: Sage Publications, Inc.

Johan Galtung, (1969), Violence, Peace, and Peace Research, Journal of Peace Research, Published by: Sage Publications, Ltd, Vol. 6, No. 3, pp. 167-191.

Kruglanski Arie W., Michele J. Gelfand, Jocelyn J. Bélanger, Anna Sheveland, Malkanthi Hetiarachchi, Rohan Gunaratna, (2014), The Psychology of Radicalization and Deradicalization: How Significance Quest Impacts Violent Extremism, international Center for Political Violence and Terrorism Research (ICPVTR), Nanyang Technological University, Singapore, Advances in Political Psychology, Vol. 35, Suppl. 1, 2014. DOI: 10.1111/pops.12163.

Kruglanski Arie W, Edward Orehek, Xiaoyan Chen, Mark Dechesne, Shira Fishman, (2009), Fully Committed: Suicide Bombers' Motivation and the Quest for Personal Significance, Political Psychology, Vol. 30, No. 3, University of Maryland, College Park.

Khashish, Fouad, (2014), Terrorism Conquer the World, Mon Liban Web, http://www.webtronic.com/monliban/afkar_full.php?id=82\#. VXXOmrXyTa3.

Lapan, H. E. and T. Sandler: 1988, 'To Bargain or Not to Bargain: That is the Question', American Economic Review 78, 16-21.

LIA Brynjar, Skjølberg Katja, 2000, Why Terrorism Occurs - A Survey of Theories and
Hypotheses on the Causes of Terrorism, FFI/RAPPORT-2000/02769, FORSVARETS FORSKNINGSINSTITUTT, Norwegian Defence Research Establishment, P O Box 25, NO2027 Kjeller, Norway.

McCrae Robert R. and Paul T. Costa, Jr., 1997, Personality Trait Structure as a Human Universal, Article in American Psychologist, Duke University Medical Center, National Institute on Aging.

McCrae, R. R., \& Costa, P. T., Jr. (1989). More reasons to adopt the five-factor model. American Psychologist, 44(2), 451-452.

McCauley, Cynthia, Ellen Van Velsor, (2004), The Center for Creative Leadership Handbook of Leadership Development, Publisher John Wiley \& Sons, Volume 29 of J-B CCL (Center for Creative Leadership), ISBN: 0787974498, 9780787974497.

Maysoum Layla, (2017) The Psychological Perspective of the Phenomenon of Terrorism: An Analytical Reading of the Personality of a Terrorist under Pathological Psychology, University of Tlemcen, Abubakar Belkaid, Algeria, an article published in the Journal of Human and Social Sciences Generation No. 36, p. 51.

Martha Crenshaw, (2008), Theories of terrorism: Instrumental and organizational approaches, Pages 13-31.

Neil J. Smelser, (2007) The Faces of Terrorism: Social and Psychological Dimensions, Princeton University Press, USA.

Nasser-Eddine, Minerva, Bridget Garnham, Katerina Agostino and Gilbert Caluya, 2011, Countering Violent Extremism (CVE) Literature Review, Counter Terrorism and Security Technology Centre, Defence Science and Technology Organisation, DSTO-TR2522, PO Box 1500, Edinburgh South Australia 5111 Australia.

Niema, Taha and M. Al-Ojaili, Sabah, 2004, Introduction to Psychology, Baghdad, Iraqi Scientific Complex, Classification No: 150, p 131.

Naim, Samir Ahmed, (1990), The Determinants of Religious Extremism in Egypt, the Arab Future Magazine, Cairo, No. 130, p. 111. 
Orabi, Mahmood AL-Said (2007), Terrorism, its concept, types, causes, effects, methods of confrontation, edition 1, Cairo - Cultural House for Publishing.

Post, J. M. (1990). Terrorist psycho-logic: terrorist behavior as a product of psychological forces. In W. Reich (Ed.) Origins of terrorism: psychologies, ideologies, theologies, states of mind (pp.25-40). New York: Cambridge University press.

Richard J. Hughbank and David L. Hughbank, (2007), Application of the Social Learning Theory to Domestic Terrorist Recruitment, Office of Justice Programs, U.S. Department of Justice, NCJ Number 222187.

Sandler, Todd, John T. Tschirhart, and Jon Cauley. (1983). A Theoretical Analysis of Transnational Terrorism. American Political Science Review, 77, 1: 36-54.

Sandler, T., \& Siqueira, K. (2009). Games and terrorism: Recent developments. Simulation \& Gaming, 40, 164-192.

Shebbi, Karim Mazal (2005) The Concept of Terrorism (A Study in International and Internal Law), Ahl al-Bayt Journal, Peace be upon them, No. 2
Silk, Andrew 2014, Research on Terrorism, Trends achievements and Failures, Forwarded Bruce Hoffman, ISBN-13: 9780714682730.

Simms, J. L. (2007). The Big Seven Model of Personality and its Relevance to Personality. Pathology, 75 (1), 65-94.

Singh, R., \& Joshi, H. (2008). Suicidal Ideation in Relation to Depression, Life Stress and Personality Among College Students. Journal of the Indian Academy of Applied Psychology, 34 (2), 259-265.

Webster (1984) Webster's New Dictionary of Synonyms, Merriam

Webster, Inc, Publishers.

Wilson, M. A. 2000. Toward a model of terrorist behavior in hostage taking incidents. Journal of Conflict Resolution 44:403-24.

Walter Reich, 1990, Ideologies, Theologies, States of Mind Mechanisms of moral disengagement. In Origins of terrorism Psychologies, 161-92.

Washington, DC: Woodrow Wilson Center Press with Johns Hopkins University Press, ISBN: 978-0-943875-89-7 paperback. 